ISSN 2078-6441. Вісник Львівського університету. Серія географічна. 2013. Випуск 41. С. 170-179. Visnyk of the Lviv University. Series Geography. 2013. Issue 41. P. 170-179.

$504.453(282.247 .78)$

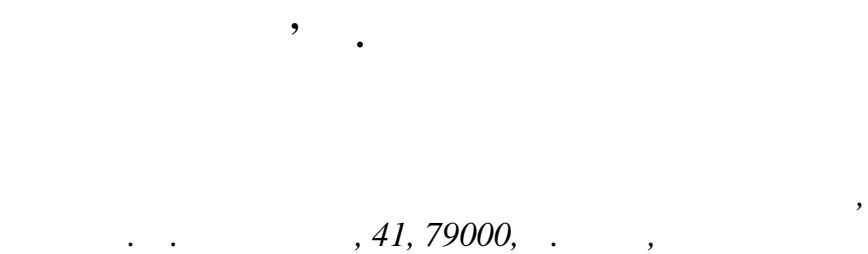

пецифік дослідження гірських водотоків кр їнських рп т поляг є в розробці т з стосув нні м ксим льно прийнятної методики досліджень. е д сть змогу комплексно оцінюв ти якісний ст н водного об'єкт . озглянуто т про н лізов но різні методологічні спекти дослідження якості вод. бгрунтов но, зокрем, використ ння методики біоіндик ції, що є невіддільною й необхідною скл довою вивчення суч сного ст ну т змін водних екосистем гірських регіонів. етодику пробов но в комплексних б г торічних дослідженнях р. рут. ведено ргумент цію використ ння методу біоіндик ції для комплексного дослідження гірських рік кр їнських рп т.

лючові слов : біоіндик ція, моніторинг, якість води, індекси якості, екосистем , річк рут.

ослідження ст ну якості вод м є першочергове зн чення для збереження унік льних вичерпних водних ресурсів. рост ння нтропогенного використ ння т експлу т ції водних об'єктів орногори, як основного джерел води для сільськогоспод рських, рекре ційних, технічних (технологічних) т питних цілей безпосередньо вплив $є$ н погіршення їхніх якісних і кількісних х р ктеристик [6]. с мперед це з бруднення побутовим сміттям, потр пляння мийних з собів, скид ння орг нічних т комун льних стоків, вирубув ння лісів, що посилює ктивність ерозійних процесів і призводить до 3 мулення т зміни долини річки (проведення ремонтно-будівельних робіт з використ нням гр війно-г лечникової суміші). ес нкціонов не скид ння з бруднюв льних речовин, т ких як, в жкі мет ли, шл ки, н фтопродукти т інші токсичні хімічні речовини, знижує якість води в ріці. огляду н це не биякої в ги н був є розробк ефективних з ходів і рекоменд цій щодо вирішення цих проблем т н укове обгрунтув ння р ціон льного водовикорист ння й охорони вод орногори у верхів'ях 6 сейну p. рут.

етодологічною основою дослідження водних об'єктів є їхнє пізн ння, що грунтується н системно-структурному підході, т кож відповідних к тегоріях т з кон х. цим підходом об'єкт дослідження розгляд ють як геосистему - просторово впорядков не системне утворення в меж х геогр фічної оболонки. истемний підхід н лежить до з г льнон укових методів дослідження, його з стосовують для системного н лізу т системного синтезу. истемний н ліз спрямов ний н дослідження внутрішньої будови т орг ніз ції річкової системи, іï структури. истемний синтез м є н меті дослідження вл стивостей системи водного об'єКт як цілого, зокрем його функцій.

ей підхід д є змогу виділити в системі водного об'єкт т кі структурні зрізи (структури): територі льний (елементи і форми розміщення чи прояву проблем, що простежуються у б сейні цього водного об’єкт ), функціон льний (н прями впливів з бруд-

(C) льчишин ., 2013 
нення), г лузевий (джерел з бруднення), інгредієнтний (речовини-з бруднюв чі), орг ніз ційно-упр влінський (систем орг нів упр вління розвитком водного 6 сейну) [2]. стосув ння системного підходу д є змогу досліджув ти водний об'єКт як скл дну дин мічну систему, уся сукупність елементів якої перебув є в певних вз ємозв'язк х і відносин х, утворюючи єдину цілісність.

од - н дзвич йно скл дний і б г тогр нний компонент, що бере уч сть у всіх біологічних т фізико-хімічних вз ємодіях з природним довкіллям. оцільно, н н шу думку, в ході дослідження ст ну якості вод вр ховув ти якомог більшу кількість критеріїв оцінки [5]. ільки комплексний н ліз усіх чинників впливу д є змогу про н лізув ти т розробити рекоменд ції щодо поліпшення якісних $\mathrm{x}$ р ктеристик.

кл дові елементи якості вод охоплюють т кі основні п р метри якості, як фізикохімічні т біологічні. ізико-хімічні п р метри - це порівняння допустимих концентр цій хімічних речовин з відповідними гр ничними зн ченнями. визн ч ють 3 тим критерієм, що м є н йменшу підпорогову т порогову концентр ції щодо певних уст лених хімічних пок зників (норм тивних пок зників). дн к дослідження винятково хімічного скл ду вод м є певні обмеження щодо декв тного відобр ження якісного ст ну водної екосистеми. ерев ги методу - у визн ченні хімічного скл ду з бруднення, недоліки - в експресності отрим ння результ тів т м тері льній з тр тності.

суч сній системі моніторингу поверхневих вод простежується тенденція переходу від винятково хімічного до біологічного контролю, який грунтується н вивченні змін у структурі й функціонув нні угрупов нь бентосних водних орг нізмів, які відобр ж ють сукупну дію середовищ н якість поверхневих вод метод [7]. сновною причиною переходу н біологічний контроль $є$ те, що угрупов ння живих орг нізмів відобр ж ють більш комплексний вплив н поверхневі води. кробентос є невіддільними біологічним компонентом річкових екосистем, який чітко відобр ж є якісний х р ктер проточної води [9].

ід ч с біоіндик ції водні об'єкти оцінюють т кл сифікують н підст ві порівняння між собою їніх метрик. етрик - це х р ктеристик біоти (ії компонент конкретного угрупов ння), як змінюється певним передб чув ним чином зі збільшенням нтропогенного н в нт ження н водойму. сновні принципи біоіндик ції розробили . ольквітц і . рсон $(1902,1908)$, які ввели поняття с пробності й біологічного с моочищення вод.

оч 6 г то орг нізмів можн використовув ти для моніторингу якості води, проте біоіндик тор ми слугують лише ті, що м ють “іде льні” х р ктеристики: т ксономічну вир зність і можливість легкого розпізн в ння; зн чне поширення, щоб порівняти д ні, зібр ні в різних р йон х; зн чну кількість, що д сть змогу, легко й б г тор зово відбир ти їхні зр зки; дост тньо великі розміри для полегшення відбору зр зків і кл сифік ції; обмежену рухливість і порівняно трив лий період життя; н явність д них про екологію орг нізму [6].

кож для моніторингу якості вод використовують риб. скільки їхня біологія, вимоги до живлення і середовищ прожив ння з г льновідомі, риби є доскон лими індик тор ми довготрив лих впливів н умови середовищ прожив ння (оскільки їх спожив ють люди, що безпосередньо вплив є н їхнє здоров'я). дн к викон ти повний відбір зр зків риб скл дно, низьк густот популяцій ускл днює достовірну інтерпрет цію отрим них д них. рім того, у певних водоток х, т ких, як м ленькі струмки, риби може не бути. скільки трив лість життя риби порівняно велик, то 
потрібен певний ч с для зміни умов якості води, які можн було 6 з фіксув ти. ому відбір зр зків риб для моніторингу якості води менше прид тний для моніторингу гірських територій.

одорості є доскон лими короткотрив лими індик тор ми якості води з вдяки швидкій репродуктивності т короткому життєвому циклу. к первинні продуценти водорості з зн ють н йбільшого впливу фізичних і хімічних нег тивних ф кторів. р зки водоростей легко відібр ти, з вд ючи мінім льної шкоди природному середовищу. роте водорості м ють дин мічні т короткотрив лі природні цикли зміни популяції. кож може не бути визн чників водоростей, для проведення їхньої ідентифік ції ч сто потрібне потужне обл дн ння.

відміну від інших видів індик торів ст ну якості вод, м кробезхребетні $є$ н лежними індик тор ми лок льних умов і специфіки місцевих впливів. кробентос момент льно ре гує н віть н короткоч сні зміни водного середовищ . скільки ці орг нізми не дуже рухливі, то можн легко, без дорогого обл дн ння, з мінім льним втруч нням у природне середовище проточних водойм відібр ти їхні зр зки. кробезхребетні широко предст влені у більшості струмків, потоків і рік, крім того, різном ніття їхніх популяцій зберіг ється н віть у м лих струмк х, де може не бути інших груп гідробіонтів. кробентос є основним джерелом їжі для б г тьох риб т інших хребетних тв рин, слугуючи основною трофічною 6 зою для них у лотичних водойм х [7]. обто від цієї групи зн чно з лежить ст більність і функціонув ння всієї гідроекосистеми. езхребетних нескл дно ідентифікув ти до великих систем тичних р нгів, дост тніх для проведення біоіндик ції [6].

цінк ст ну гідроценозів гірських рік кту льн, оскільки їхні кв торії розміщенні як у природно непорушених високогірних територіях, т к і н територіях з суттєвим нтропогенним н в нт женням (н селені пункти, промислові підприємств, сільськогоспод рські угіддя, оздоровчі й рекре ційні з кл ди, дороги, комунік ції тощо).

етодик біоіндик ції пробов н, ïï використовують у світі, що д є змогу порівнюв ти іiі результ ти т н лізув ти ст н н вколишнього середовищ у глоб льних м сшт 6 х [8].

ля об'єктивного і комплексного вивчення гідроекологічного ст ну водної екосистеми ми проводили систем тичні, щосезонні дослідження верхів'я руту н території

рп тського н ціон льного п рку т міст орохт і ремч протягом 2007-2010 pp. г лом обр но вісім точок спостереження, що розміщені вниз 3 течією перед і після можливих місць н дходження з бруднюв льних речовин у воду р. рут.

г льн довжин ріки до вп д ння в р. ун й -967 км, у меж х кр їни -299 км.

г льн площ водозбору - $27500 \mathrm{kм}^{2}$, у меж х н шої держ ви - $17400 \mathrm{kм}^{2}$ [1]. ослідження методом біоіндик ції з поч тков ні в липні 2007 р. проводили щосезону - зим -весн -літо-осінь упродовж трьох років спільно з к ндид том біологічних н ук, н уковим співробітником нституту екології рп т кр їни . икитч ком.

г лом для біоіндик ційного н лізу використовують літній період, проте для 3 г льного розуміння процесів с моочищення й з бруднення води (як природного, т к і нтропогенного) викон но біологічний н ліз якості води в усі сезони.

ля біоіндик ції верхів'я р. рут з стосовув ли дв індекси: рент-біотичний індекс (Trent Biotic Index, TBI) т його модифік цію розширений біотичний індекс (Extended Biotic Index, EBI). ндекс розробив . удівіс (1964) для індик ції води нглійської ріки рент. ей індекс сьогодні є одним 3 н йпоширених, які використо- 
вують у кр їн х вропи й у світі з г лом [11]. ндекс грунтується н предст вленості у водоймі орг нізмів, що н леж ть до індик торних, груп т н їхній чисельності. $p$ зі підвищення ступеня з бруднення водойми предст вники цих груп зник ють з угрупов ння в певній послідовності. ля збільшення чутливості цих індексів під ч с обчислення використовув ли т кож чисельність тв рин індик торних груп (т бл. 1) [7].

ок зники розр хунку індексу

\begin{tabular}{|c|c|c|c|c|c|c|c|}
\hline \multirow{2}{*}{ иди-індик тори } & \multirow{2}{*}{$\begin{array}{c}\text { ількість } \\
\text { в идів інди- } \\
\text { к торів }\end{array}$} & \multicolumn{6}{|c|}{ г льн кількість груп бентосних орг нізмів } \\
\hline & & 0-1 & $2-5$ & 6-10 & 11-15 & $16-20$ & більше 20 \\
\hline \multirow{2}{*}{$\begin{array}{l}\text { ичинки веснянок } \\
\text { (Plecoptera) }\end{array}$} & ільше 1 & - & 7 & 8 & 9 & 10 & 11 \\
\hline & 1 вид & - & 6 & 7 & 8 & 9 & 10 \\
\hline \multirow{2}{*}{$\begin{array}{l}\text { ичинки одноденок } \\
\text { (Ephemeroptera) }\end{array}$} & ільше 1 & - & 6 & 7 & 8 & 9 & 10 \\
\hline & 1 вид & - & 5 & 6 & 7 & 8 & 9 \\
\hline \multirow{2}{*}{$\begin{array}{l}\text { ичинки волохокрильців } \\
\text { (Trichoptera) }\end{array}$} & ільше 1 & - & 5 & 6 & 7 & 8 & 9 \\
\hline & 1 вид & 4 & 4 & 5 & 6 & 7 & 8 \\
\hline окопл ви Gammaridae & & 3 & 4 & 5 & 6 & 7 & 8 \\
\hline $\begin{array}{l}\text { одяний ослик } \\
\text { (Asellus aquaticus) }\end{array}$ & & 2 & 3 & 4 & 5 & 6 & 7 \\
\hline Oligochaeta + Chironomidae & & 1 & 2 & 3 & 4 & 5 & 6 \\
\hline
\end{tabular}

ісля визн чення кількості ідентифіков них у пробі груп зн ходимо відповідний стовпець у т бл. 1 . перехресті стовпця і рядк є індекс ТВІ, що х р ктеризує досліджув ний створ ріки.

ндекс мє чотириб льну гр д цію й $\mathrm{x}$ р ктеризує с пробність водойми (т бл. 2) [4].

блиця 2 сновним недоліком індексу є м л кіль-

л сифік ція якості води з кість гр д цій. крім того, біоіндик тори є доволі індексом [5]

\begin{tabular}{|c|c|}
\hline ількість б лів & ип водойми \\
\hline о 3 & оліс пробний \\
\hline $3-6$ & $\alpha$-Мезос пробний \\
\hline $6-8$ & $\beta$-Мезос пробний \\
\hline он д 8 & лігос пробний \\
\hline
\end{tabular}
великими т ксономічними груп ми. огляду н це з пропонов но дет льніший індекс EBI [11]. етод розр хунку н логічний до методу , у розр хунку індексу вр ховують менші т ксони індик торних груп, які тяжіють до орг нічно б г тших вод, ніж уся груп з г лом. кож у цьому індексі збільшен кількість гр д цій від 4 до 5 (див. т бл. 3) [7].

. еменченко використ в 16 індексів для оцінки якості води р. ерезин, що протік $є$ н території ерезинського н ціон льного 3 повідник в ілорусі [7]. ході порівняльного н лізу отрим них результ тів втор виявив, що н йбільший коефіцієнт кореляції є с ме для індексів й , тому під ч с досліджень ми використовув ли одноч сно дв індекси. нші ж індекси, що грунтуються н видовому чи родовому т ксономічному скл ді бентосу, д ли в р зі порівняння доволі різні результ ти.

і п’ять к тегорій кл сифік ції відповід ють п'ятьом к тегоріям якості води, прийнятим у н шій держ ві: відмінн, добр, 3 довільн, пог н, дуже пог н . укр їнській кл сифік ції друг й третя к тегорії розділені н дві підк тегорії: добр дуже добр й добр , з довільн - з довільн й посередня. і дві к тегорії ми т кож розділяли н підк тегорії відповідно до б льної оцінки (див. т бл. 4) [4]. 
ок зники розр хунку індексу

[5]

блиця 3

\begin{tabular}{|c|c|c|c|c|c|c|c|c|c|c|}
\hline \multirow[b]{2}{*}{ иди індик тори } & \multirow{2}{*}{$\begin{array}{c}\text { ількість } \\
\text { видів індик - } \\
\text { торів }\end{array}$} & \multicolumn{9}{|c|}{ Г ЛЬн } \\
\hline & & 0-1 & $2-5$ & 6-10 & $11-15$ & $16-20$ & $21-25$ & $26-30$ & $31-35$ & $>35$ \\
\hline \multirow{2}{*}{$\begin{array}{l}\text { ичинки веснянок } \\
\text { (Plecoptera) }+ \\
\text { Leuctra } \\
\end{array}$} & ільше 1 & - & - & 8 & 9 & 10 & 11 & 12 & 13 & 14 \\
\hline & 1 вид & - & - & 7 & 8 & 9 & 10 & 11 & 12 & 13 \\
\hline \multirow{2}{*}{$\begin{array}{l}\text { ичинки одноденок } \\
\text { (Ephemeroptera) без } \\
\text { Baetidae і Caenidae }\end{array}$} & ільше 1 & - & - & 7 & 8 & 9 & 10 & 11 & 12 & - \\
\hline & 1 вид & - & - & 6 & 7 & 8 & 9 & 10 & 11 & - \\
\hline \multirow{2}{*}{$\begin{array}{l}\text { ичинки волохокриль- } \\
\text { ців (Trichoptera) + } \\
\text { Baetidae і Caenidae }\end{array}$} & ільше 1 & - & 5 & 6 & 7 & 8 & 9 & 10 & 11 & - \\
\hline & 1 вид & - & 4 & 5 & 6 & 7 & 8 & 9 & 10 & - \\
\hline $\begin{array}{c}\text { окопл ви } \\
\text { (Gammaridae) }\end{array}$ & & - & 4 & 5 & 6 & 7 & 8 & 9 & 10 & - \\
\hline $\begin{array}{c}\text { одяний ослик } \\
\text { (Asellus aquaticus) }\end{array}$ & & - & 3 & 4 & 5 & 6 & 7 & 8 & 9 & - \\
\hline $\begin{array}{l}\text { Oligohaeta+ } \\
\text { Chironomidae }\end{array}$ & & 1 & 2 & 3 & 4 & 5 & 6 & - & - & - \\
\hline
\end{tabular}

зн чимо, що висок оцінк якості води з цими індекс ми відповід є лише ет лонним ділянк м рік, які пр ктично не з зн ють прямої чи опосередков ної нтропопресії [7].

ідробіологічний м тері л відбир ли й опр цьовув ли з г льноприйнятими в гідробіології т екології метод ми. кожному створі обир ли стометровий відрізок ріки, де проби відбир ли в трьох одн кових біотоп х (н ділянк х зі швидкою течією й глибиною 0,2-0,3 м). ксономічний скл д груп-індик торів вст новлюв ли 3 визн чник ми . епневої (1964).

підст ві усереднення д них вл сних досліджень $з$ 2007-2009 pp. отрим но т кі результ ти: вод р. рут вище “ росляк" $є$ високої з кл сифік цією (відмінної - 3 норм тив ми кр їни) якості, пок зники індексів колив ються в меж х 7,9 (літо 2007), 7,5 (зим /осінь 2008), 9,5 (літо 2009). йвищі зн чення х р ктерні для створу вище “" росляк ”, де нем будь-якої господ рської діяльності, 3 фіксов но лише рекре ційне н в н-

блиця 4

л сифік ція якості води з індексом

\begin{tabular}{|c|c|c|}
\hline н чення & кість води & 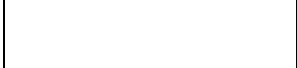 \\
\hline ід 10 & исок & ідмінн \\
\hline $9-10$ & \multirow{2}{*}{ обр } & уже добр \\
\hline $8-9$ & & обр \\
\hline $7-8$ & \multirow{2}{*}{ евисок } & довільн \\
\hline $6-7$ & & осередня \\
\hline $4-6$ & ИЗЬК & ОГ $\mathrm{H}$ \\
\hline o 4 & ез довільн & уже пог н \\
\hline
\end{tabular}

т ження, з смічення побутовим сміттям т ущільнення грунту вн слідок витоптув ння. цій ділянці вод дуже доброї якості й олігос пробн [5].

ідр зу ж з місцем скиду неочищених стічних вод туристичної б зи якість води погіршується до доброї і є $\beta$-мезос пробною. ок зники колив ються в меж х 7,5 (зим 2008), 8 (осінь 2008), 7 (літо 2009). к тенденція спостеріг ється в усі сезони, тобто відбув ється з бруднення спортивно-туристичною б зою “" росляк” р. рут н території рп тського 
ижче “ росляк” "н створ х вод руту н був л доброї й з довільної якості (рис. 1, 2). відтинку ріки від вп діння притоки омулець і до ділянки з орохтою зн чення й ЕВІ колив ються в меж х 7 (літо 2007), 7,5-8,0 (зим /осінь 2008), 8,5 (літо 2009). о орохти пок зники є в меж х доброї й дуже доброї якості, нижче орохти - перев жно невисокої (посередньої й з довільної). лігос пробною рік є до орохти.

ижче орохти вод ст $є \beta$-мезос пробною, пок зники якості вод н йнижчі (див. рис. 3). ок зники біоіндик ції колив ються в меж х 6 (літо 2007), 7 (зим /осінь 2008), 7,5-8,0 (літо 2009). е пояснюють господ рською освоєнністю території т збільшенням кількості скид ння з бруднюв льних компонентів у річку н території смт орохт .

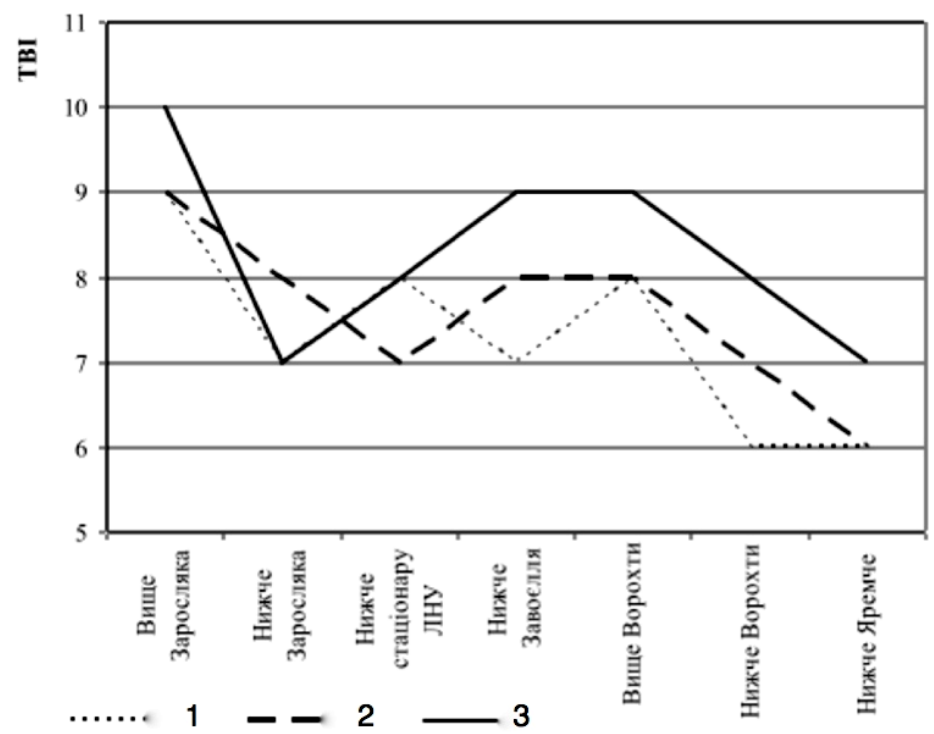

ис. 1. ок зники зн чень індексу у верхів'ї р. рут з 2007 (1), 2008 (2), 2009 (3) pp.

ремч спостеріг ємо погіршення пок зників якості води вн слідок збільшення інфр структури, що з бруднює рут скид ми більшої кількості стічних вод, твердих побутових відходів, будівельного сміття т н фтопродуктів уздовж втомобільної дороги біля ріки. ок зники біоіндик ції - 6 (літо 2007), 6,5 (зим /осінь 2008), 7,5 (літо 2009).

г лом т кі кл си с пробності х р ктерні для гірських водойм. окрем , $95 \%$ льодовикових озер, озерець і боліт орногори в суб льпійському й льпійському пояс х є $\beta$-мезос пробними і лише $5 \%$ - олігос пробними.

підст ві порівняння результ тів н ших досліджень 3 три роки можн стверджув ти, що регулярними з бруднюв ч ми верхів'я р. рут є 63 “ росляк”, у якій не пр цюють очисні споруди, судячи 3 гідрохімічними н ліз ми 2008 р., і н селені пункти орохт й ремч [1]. н чну моз їчність якості річкової води створюють нерегулярні й різном сшт бні з бруднення вн слідок дорожніх ремонтних робіт і нерегульов ної рекре ції, з бруднення різном нітними вид ми твердих побутових відходів т будівельним сміттям. чевидно, певну роль у з брудненні ріки відігр ють і промислові підприємств . 
н чні зміни в якості вод руту, н н шу думку, відбув ються і вн слідок повеней, які переміщ ють орг нічні й неорг нічні донні відкл ди н великих ділянк х ріки. мив ння к міння й знесення вниз орг ніки в поток х і н копичення їх у ділянк х 3 повільнішою течією, очевидно, т кож вплив ють н очищення верхів'я гірських рік. іки т к “оновлюють” своє русло.

ід ч с біоіндик ції якості води приток р. рут омульця, орещ нки, зірного 3 фіксов но вищу якість їхніх вод порівняно з рутом ( для р. рут у цих ділянк х - 7-8 б лів, приток - 9; н логічно й для зн чень ). риток врилець біля місця вП діння м є одн кову якість води з р. рут -8 б лів для й . тже, для p. рут $є \mathrm{x}$ р ктерним очищення 3 вдяки чистішим приток м, що підтримує якість води н високому рівні, хоч окремі ділянки ріки з зн ють зн чного з бруднення.

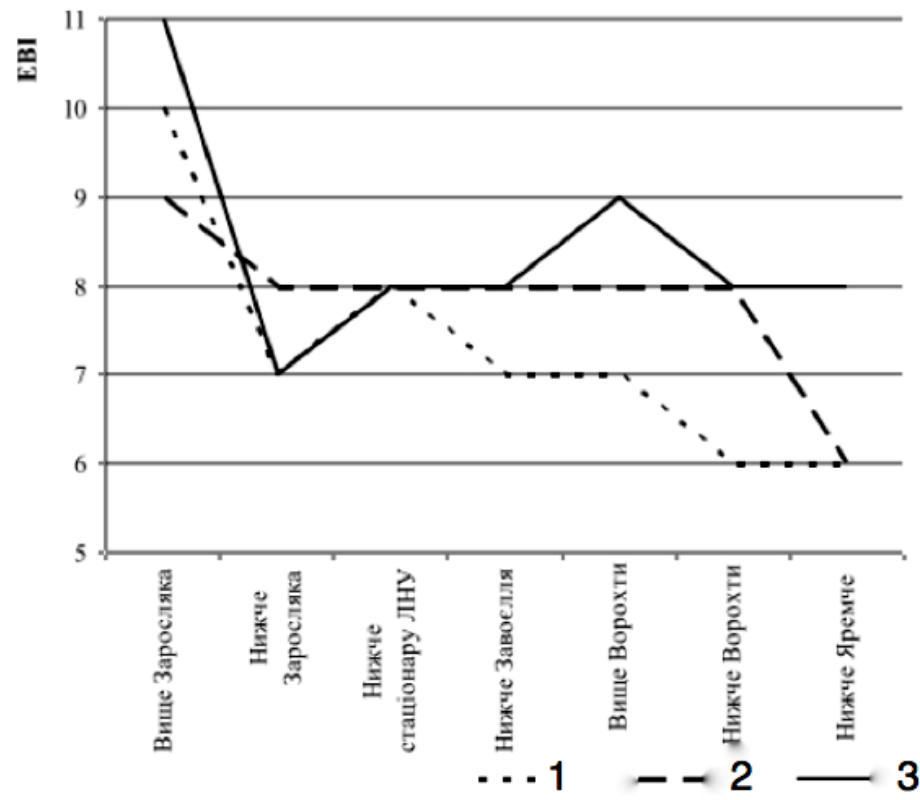

ис. 2. ок зники зн чень індексу Е у верхів’ї р. рут з 2007 (1), 2008 (2), 2009 (3) pp.

усередненими д ними 2007-2009 рр. ми отрим ли т кі результ ти: вод р. рут вище “ росляк" є високої з кл сифік цією (відмінної з норм тив ми кр їни) якості, до орохти - доброї (доброї й дуже доброї) якості, нижче орохти - перев жно невисокої (посередньої й з довільної). лігос пробною рік є до орохти, нижче $\beta$-мезос пробною (див. рис. 3). іст вивши дин міку зміни якості вод у 2009 р., ми виявили невелике підвищення пок зників якості води н 1,0-1,5 б ли (див. рис. 2).

н шу думку, це пов'яз но з п водк ми у 2008 р. т н ступною регенер цією водної екосистеми.

вдяки н лізу отрим них результ тів якості вод методом біоіндик ції безз перечно переконуємося в необхідності використ ння цього методу в дослідженнях водних екосистем, оскільки угрупов ння бентосних водних орг нізмів (гідроценози) декв тно (момент льно) ре гують н з бруднення чи зміну якісних х р ктеристик водойми, відобр ж ють сукупну дію середовищ н якість поверхневих вод. і угрупов ння д ють змогу оцінити ст н водної екосистеми н обр них ділянк х у комплексі, не 


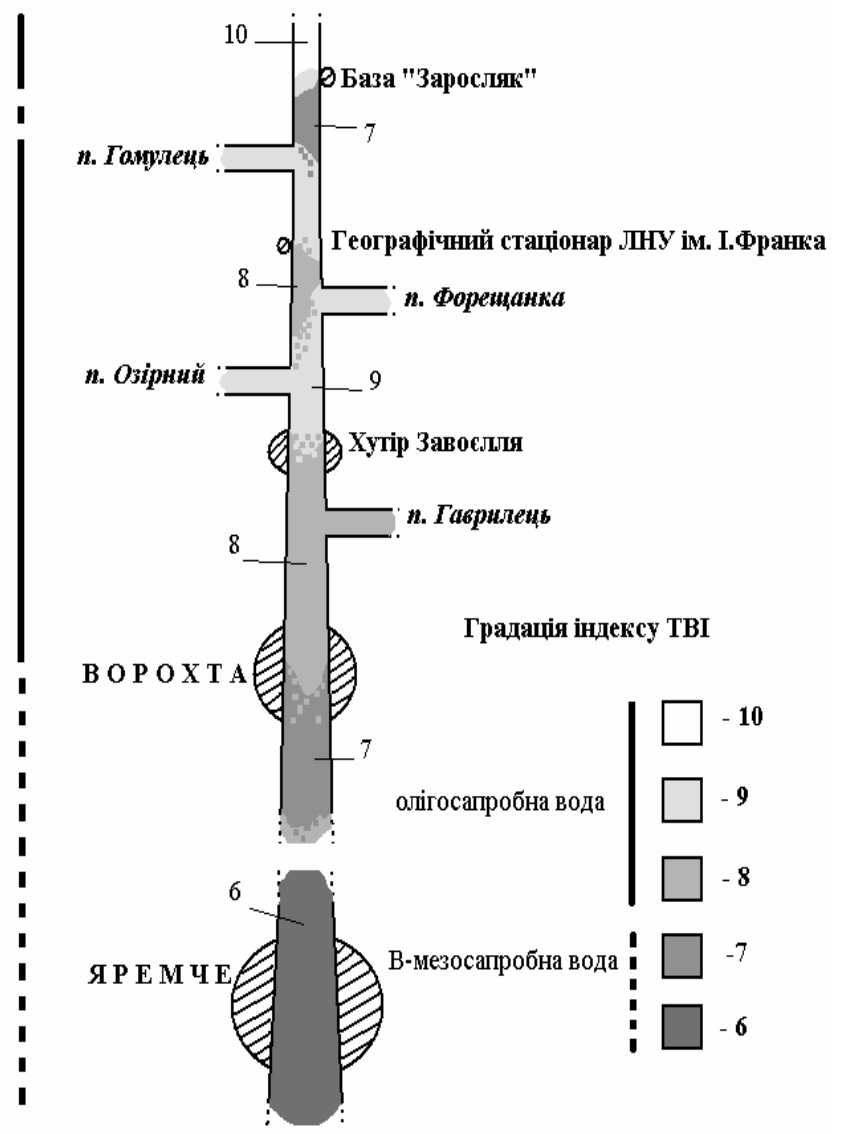

ис. 3. ртосхем якості води верхів’я р. рут (усереднені д ні з 2007-2009 рр.) [4].

отрим ти тільки певні пок зники, які прирівнюють до норм $\quad$ чи $\quad$-ів. етодик біоіндик ції не витісняє, доповнює фізико-хімічні способи дослідження. орівнюючи і зіст вляючи результ ти, опр цьов ні методикою біоіндик ції, з фізико-хімічними т гідрологічними пок зник ми, отримуємо н йбільш об'єктивну інформ цію про ст н водної екосистеми.

\section{СПИСОК ВИКОРИСТАНОЇ ЛІТЕРАТУРИ}

1. ищневський . . ідрологічні х р ктеристики річок кр їни / . . ишневський, . . осовиць. - . : ік - ентр, 2003. - 324 с.

2. укурудз . . ідроекологічні проблеми суходолу / . . укурудз . - ьвів : віт, 1999. $-230 \mathrm{c}$.

3. укурудз . . изн чення якості природних вод у контексті моніторингу геосистем / . . укурудз . - ьвів, 1994. - 78 с.

4. икитч к. . віт про н уково-дослідну роботу з договірною темою № 29 2009 “ іоіндик ція води р. рут” / . . икитч к. - 2009. 
5. икитчк . . іоіндик ція річки рут / . . икитч к, . . ожко, . . льчишин // тері ли н ук.-пр кт. конф. “ риродні комплекси й верхів’я річки рут". - ьвів, 2009. - . 206-213.

6. ожкко . . езульт ти гідроекологічних досліджень верхів'я річки рут / . . ожко, . . льчишин, . . икитч к // тері ли н ук.-пр кт. конф. “" риродні комплекси й верхів'я річки рут”. - ьвів, 2009. - 185-190.

7. еменченко . . ринципы и системы биоиндик ции текучих вод / . . еменченко. - инск : pex, 2004. - 125 с.

8. Ilczyszyn Y. Stan ekologiczny obiektow wodnych Czornohory / Y. Ilczyszyn, O. Lenko // Materiały konferencji "Homo Naturalis". - Katowice, 2009. - S. 156-165.

9. Karr J. R. Assessing biological integrity in running waters: a method and its rationale / J. R. Karr, K. D. Fausch, P. L. Angermeier, P. R. Yant, I. J. Schlosser // Illinois Natural History Survey. Special Publication. - Illinois, 1986. - N 5. - 28 p.

10. Kolkwitz R. Ökologie der pflanzlichen Saprobien / R. Kolkwitz, M. Marsson // Berichte der Deutschen Botanischen Gesellschaft. - 1908. - Band 26a. - P. 505-519.

11. Woodiwiss F.S. Comparative study of biological-ecological water quality assessment methods / F. S. Woodiwiss // Summary Report. Commission of the European Communities / Seven Trent Water Authority. UK. - 1978. - 45 p.

m ття: н дійшл до ред кцї̈ 09.11.2012

доопр иьов н 14.12 .2012

прийнят до друку 20.02.2013

\title{
RESULTS OF RESEARCH OF ECOLOGICAL CONDITION OF WATER QUALITY OF HEADWATERS OF PRUT RIVER BY BIOINDICATION METHOD
}

\author{
Yaroslav Ilchyshyn \\ Ivan Franko National University of Lviv, \\ P. Doroshenko St., 41, UA - 79000 Lviv, Ukraine
}

Specifics of the watercourses research in Ukrainian Carpathian Mountains is in developing and using the most appropriate research methods. This will objectively and comprehensively assess the quality situation of water objects. Were reviewed and analyzed different methodological aspects of water quality researching. The use of bioindication methods that are an integral and necessary part of researching the current situations and changes in water (river) ecosystems of mountain regions is substantiated. The methods were used in long-term and comprehensive research of river Prut and the article represents a summary of the results. Argumentation of using this bioindication method in an integrated research of mountain rivers of the Ukrainian Carpathian Mountains is given.

Key words: bioindication, monitoring, water quality, ecosystems, research methods, indices of quality. 


\title{
росл в Льчишин
}

\author{
ьвовский н цион льный университет имени в н \\ ул. . орошенко, 41, 79000, г. ьвов, кр ин
}

пецифик исследов ния горных водотоков кр инских рп т состоит в $р$ зр ботке и использов нии м ксим льно приемлемой методики исследов ний. то д ет возможность объективно, комплексно оценить к чественное состояние водного объект . ссмотрено и про н лизиров но методологические спекты исследов ния к честв вод. боснов но в отдельности использов ние методики биоиндик ции, что является неотъемлемой и необходимой ч стью изучения современного состояния и изменения водных экосистем горных регионов. етодик пробиров н в комплексных многолетних исследов ниях p. рут. редложено результ ты, ргументиров но использов ние метод биоиндик ции при комплексном исследов нии горных рек кр инских рп т.

лючевые слов : биоиндик ция, мониторинг, к чество воды, экосистем , методы исследов ния, индексы к честв . 